\title{
Role of progesterone in the control of endometrial oxytocin receptors at luteolysis in sheep
}

\author{
T. M. Lau ${ }^{1 *}$, D. J. Kerton ${ }^{1}$, C. B. Gow ${ }^{2}$ and R. J. Fairclough ${ }^{1} \dagger$ \\ ${ }^{1}$ Victoria Institute of Animal Science, Werribee, Victoria 3030, Australia; and ${ }^{2}$ School of Agriculture, \\ La Trobe University, Bundoora, Victoria 3083, Australia
}

\begin{abstract}
Merino ewes were given a prostaglandin synthetase inhibitor, Finadyne (50 mg flunixin meglumine $\mathrm{ml}^{-1}$ ), on days 14-16 of the oestrous cycle (day of oestrus $=$ day 0 ), Finadyne on days $14-16$ plus $\mathrm{PGF}_{2 \alpha}$ on days $15-16$, or progesterone on days 14-17 plus $\mathrm{PGF}_{2 \alpha}$ on days 15-16. Blood samples were taken once a day on days 10-14 and three times a day on days 15-16 for progesterone measurement. The concentrations of oxytocin receptors were measured in the endometrial (pooled caruncular and intercaruncular) tissues collected on day 17. Treatment of ewes with Finadyne resulted in the maintenance of high plasma concentrations of progesterone and a small, but nonsignificant, reduction in the concentrations of endometrial oxytocin receptors. Co-administration of $\mathrm{PGF}_{2 a}$ reversed this effect of Finadyne. Treatment with both progesterone and $\mathrm{PGF}_{2 \alpha}$ increased the concentrations of progesterone in plasma and significantly reduced the concentrations of endometrial oxytocin receptors compared with those in the control ewes. These data indicate that withdrawal of progesterone from the circulation as a result of spontaneous luteolysis or by a $\mathrm{PGF}_{2 \alpha}$-induced luteolysis caused an increase in the concentrations of oxytocin receptors. However, maintenance of plasma progesterone concentrations over the period of normal luteolysis only partially inhibited the concentrations of endometrial oxytocin receptors. These results suggest that the increase in the concentrations of oxytocin receptors at luteolysis in the naturally cycling ewes may be due to the loss of the inhibitory effects of progesterone on uterine oxytocin receptors.
\end{abstract}

\section{Introduction}

Evidence has been accumulating for the involvement of progesterone in the regulation of endometrial oxytocin receptors in ewes. The increase in the concentration of oxytocin receptors around luteolysis in ewes has been shown to coincide with a fall in the concentrations of progesterone in plasma (Roberts $e t$ al, 1976; Sheldrick and Flint, 1985). In parturient rats, treatment with a PG synthetase inhibitor, Naproxen, reduced the concentrations of oxytocin receptors, whereas co-administration of PG increased the receptor concentrations (Chan, 1987; Chan et al., 1988). However, the maintenance of the corpus luteum is associated with the maintenance of high concentrations of progesterone in plasma and exogenous progesterone given to ovariectomized ewes for 10-12 days can reduce the concentrations of oxytocin receptors in the endometrium (Vallet et al., 1990; Lau et al., 1992a). Withdrawal of progesterone treatment was followed by a rapid rebound in the concentrations of endometrial oestrogen receptors in the nucleus (Leavitt et al., 1985) and endometrial oxytocin receptors (Leavitt et al., 1985;

\footnotetext{
*Present address: Department of Obstetrics and Gynaecology, Monash University, Clayton, Victoria 3168, Australia.

tPresent address: Department of Applied Science, Victoria University of Technology, St Albans, Victoria 3021, Australia.

Received I July 1992.
}

Lau et al., 1992b) in ovariectomized ewes regardless of whether a constant infusion of oestradiol was given. However, it is not clear whether the increase in the concentrations of oxytocin receptors in cyclic ewes during luteolysis is due to the withdrawal of progesterone inhibition. The present experiment was designed to investigate whether the removal of progesterone inhibition during luteolysis is responsible for the increase in the concentration of endometrial oxytocin receptors in ewes.

\section{Materials and Methods}

\section{Animals and treatments}

Twenty four 3-4-year-old Merino ewes were synchronized for oestrus by inserting a controlled internal drug release (CIDR) device impregnated with $300 \mathrm{mg}$ progesterone (Eazibreed CIDR G, Riverina Artificial Breeders, Australia) into the vagina for 10 days and giving an i.m. injection of $5 \mathrm{mg}$ of a $\mathrm{PGF}_{2 \alpha}$ analogue Lutalyse (Upjohn, Australia) one day before the removal of the CIDR. The ewes were then randomly allocated to four treatment groups $(n=6)$. The control ewes in Group I were given i.m. injections of saline; Group 2 ewes were given i.m. injections of a PG synthetase inhibitor, Finadyne (containing $50 \mathrm{mg}$ flunixin meglumine $\mathrm{ml}^{-1}$ in saline solution; Schering, 
USA) $1 \mathrm{ml}$ twice daily at $8: 00 \mathrm{~h}$ and $20: 00 \mathrm{~h}$ on days $14-16$ inclusive; Group 3 ewes were given Finadyne on days 14-16 plus i.m. injections of $\mathrm{PGF}_{2 \alpha}$ (Lutalyse) at $1.5 \mathrm{mg}$ twice a day on days $15-16$ at the times indicated above; and Group 4 ewes were given progesterone by the insertion of a CIDR into the vagina at $08: 00 \mathrm{~h}$ on day 14 and $\mathrm{PGF}_{2 \alpha}$ injections at the times indicated above.

Blood samples $(6-8 \mathrm{ml})$ were taken by venepuncture for measurement of progesterone concentrations once a day at $8: 00 \mathrm{~h}$ on days $10-14$, and once every $8 \mathrm{~h}$ from day 15 until the morning of day 17 . Hysterectomy was performed under general anaesthesia on the morning of day 17 , and the uteri were excised and collected onto ice. The endometrial microsomes containing oxytocin receptors were prepared from pools of caruncular and intercaruncular tissues, according to the procedure described by Lau et al. (1992a).

\section{Progesterone assay}

Concentrations of progesterone in plasma were measured using a direct progesterone $\left[{ }^{125} \mathrm{I}\right]$ radioimmunoassay kit purchased from Farmos Diagnostica, Finland (Lau et al., 1992a). The sensitivity of the assay was $0.5 \mathrm{nmoll}^{-1}$. The crossreactivity of the antisera for progesterone, $11 \beta$-hydroxyprogesterone, $5 \alpha$-dihydroprogesterone, $5 \beta$-dihydroprogesterone, hydroxyprogesterone derivatives, pregnen derivatives, corticoids, testosterone and oestrogens was $100 \%, 75 \%, 8.8 \%, 7.1 \%,<0.3 \%$, $<0.3 \%,<0.01-1 \%,<0.01 \%$ and $<0.01 \%$, respectively. Comparisons were made between this kit assay and the extraction assay (Fairclough et al., 1975) used in our laboratory. The correlation coefficient between the two assays was $0.996(n=10)$ (Parr, 1991). The intra- and interassay coefficients of variation, for a plasma pool collected from pregnant ewes on day 10 of pregnancy, were $6.5 \%(n=10)$ and $12.6 \%(n=10)$, respectively.

\section{Assay of endometrial oxytocin receptors}

The endometrial microsomal fractions containing oxytocin receptors were prepared and the oxytocin receptors were measured by a receptor-binding assay described by Lau et al. (1992a). All samples were measured in one assay and the intraassay coefficient of variation for the receptor binding radioimmunoassay was $3 \%(n=4)$. The receptor-binding data were subjected to Scatchard (1949) analyses to determine the affinity $\left(K_{d}\right)$ and oxytocin receptor concentrations. The protein concentrations of the samples were measured by a Bio Rad Protein Kit II (Bio Rad, USA) using a BSA (Fraction V) standard (Sigma, St Louis, MO).

\section{Statistical analysis}

All data were analysed by one-way analysis of variance. The differences in the concentrations of oxytocin receptors and the affinity of the receptors were compared between treatments. Comparisons were also made between ewes with low (pooled data of Groups 1 and 3) and high (pooled data of Groups 2 and 4) plasma progesterone concentrations at the time of hysterectomy, and ewes given (pooled data of Groups 3 and 4) or not given $\mathrm{PGF}_{2 a}$ (pooled data of Groups 1 and 2). Variances are expressed as standard error of the mean (SEM).

\section{Results}

\section{Plasma progesterone concentration}

Four of the six control ewes underwent spontaneous luteolysis between days 15 and 16 as judged by the peripheral progesterone profile (Fig. 1a). One ewe (Ewe 334) had an extended cycle with progesterone concentrations in peripheral plasma remaining above $11.13 \mathrm{nmol}^{-1}$ until the morning of day 17 . The remaining ewe (Ewe 137) in this group had a short cycle duration and progesterone concentrations in peripheral plasma were below detectable values by day 11 . The data from these two ewes were excluded from analyses.

All ewes in Group 2, which were given injections of Finadyne, had an extended cycle with peripheral progesterone concentrations above $6.36 \mathrm{nmol} \mathrm{l}^{-1}$ until day 17 (Fig. Ib). The ewes in Group 3, which were given Finadyne and $\mathrm{PGF}_{2 \alpha^{\prime}}$ underwent synchronized luteolysis and the peripheral plasma concentrations of progesterone fell below detectable values by $16: 00 \mathrm{~h}$ on day 16 (Fig. 1c). The progesterone concentrations in peripheral plasma in Group 4 ewes, which were given a progesterone impregnated CIDR and $\mathrm{PGF}_{2 \alpha}$ injections, were still high (above $6.36 \mathrm{nmol}^{-1}$ ) on day 17 (Fig. Id).

\section{Endometrial oxytocin receptors}

Scatchard analysis of the receptor binding data yielded straight lines with an average apparent $K_{\mathrm{d}}$ value of $1.74( \pm 0.11)$ nmol I ${ }^{-1}$. There was no significant $(P>0.05)$ difference in the receptor affinity among treatment groups.

The mean concentrations of endometrial oxytocin receptors, defined as the amount of $\left[{ }^{3} \mathrm{H}\right]$ oxytocin bound $\mathrm{mg}^{-1}$ microsomal protein, for all treatment groups, are summarized (Fig. 2). There was a significant $(P<0.002)$ overall treatment effect on oxytocin receptor concentrations. The mean concentration of oxytocin receptors in the control ewes (Group 1) was high $\left(1596 \pm 243 \mathrm{fmol} \mathrm{mg}^{-1}\right.$ protein). This concentration was comparable to those reported previously (Sheldrick and Flint, 1985) and was significantly higher than those observed during the late luteal phase $\left(10-30 \mathrm{fmol} \mathrm{mg}^{-1}\right.$ protein: Sheldrick and Flint, 1985). The mean receptor concentrations of the Finadynetreated ewes (1161 $\pm 98 \mathrm{fmol} \mathrm{mg}^{-1}$ protein) were lower than in the control ewes, but the difference was not statistically significant $(P>0.05)$. However, there was a significant $(P<0.02)$ reduction in the oxytocin receptor concentrations in ewes given Finadyne alone compared with those found in the ewes given both Finadyne and $\mathrm{PGF}_{2 a}\left(1919 \pm 235 \mathrm{fmol} \mathrm{mg}^{-1}\right.$ protein) that had undergone synchronized luteolysis. Ewes given progesterone plus $\mathrm{PGF}_{2 \alpha}$ (Group 4$)$ had significantly $(P<0.05)$ lower oxytocin receptor concentrations $\left(743 \pm 166 \mathrm{fmol} \mathrm{mg}^{-1}\right.$ protein) than those found in the control ewes (Group 1) and Finadyne plus $\mathrm{PGF}_{2 a}$-treated ewes (Group 3).

The concentrations of oxytocin receptors were significantly $(P<0.01)$ lower in ewes with high plasma progesterone concentrations (pooled Groups 2 and 4) than in those with low plasma progesterone concentrations (pooled Groups 1 and 3) at the time of hysterectomy on day 17 (Fig. 3). In the control 


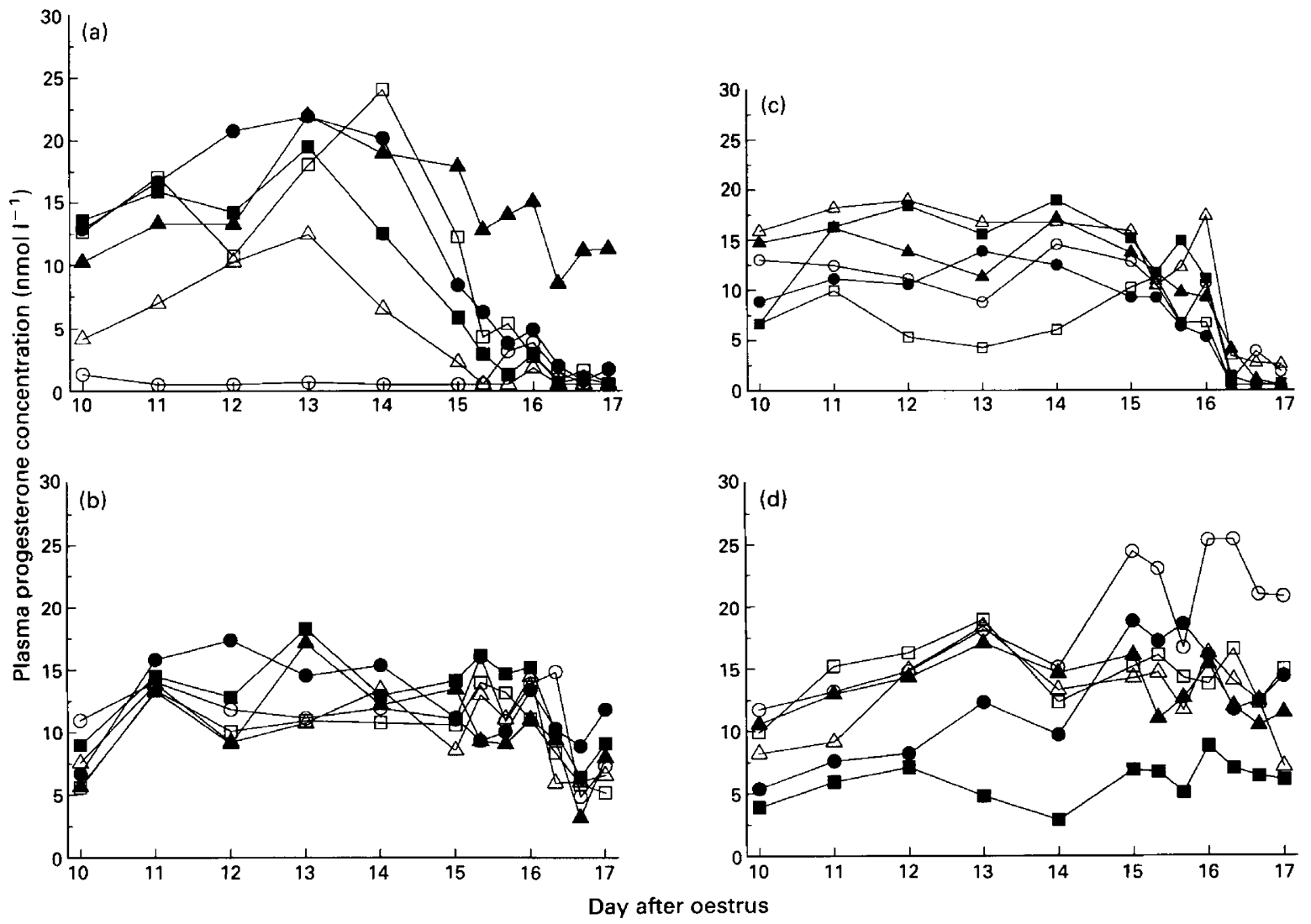

Fig. 1. Concentrations of progesterone in plasma of each individual ewe $(n=6)$ around the time of luteal regression. The ewes were given (a) injections of saline (control); (b) Finadyne (50 mg flunixin meglumine, twice a day on days 14-16); (c) Finadyne plus $\mathrm{PGF}_{2 \alpha}(1.5 \mathrm{mg}$, twice a day on days $15-16)$ or (d) progesterone (intravaginal CIDR) plus $\mathrm{PGF}_{2 \alpha}$. Ewe $334(\mathbf{A})$ and Ewe $137(\mathrm{O})$ in panel (a) had extended and short cycle duration, respectively.

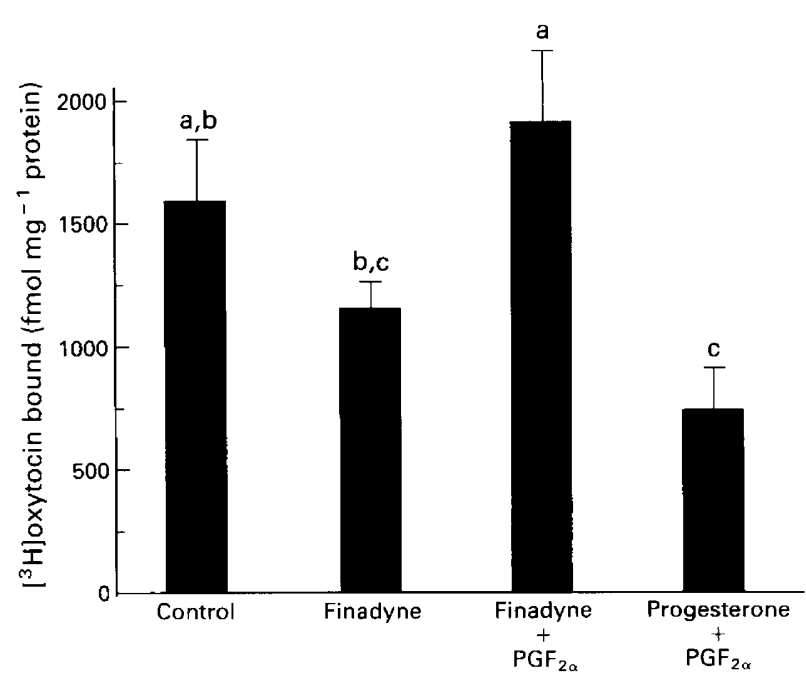

Fig. 2. Endometrial oxytocin receptor concentrations (expressed as fmol $\left[{ }^{3} \mathrm{H}\right.$ loxytocin bound $\mathrm{mg}^{-1}$ protein) on day 17 in ewes given injections of saline (control); Finadyne $(50 \mathrm{mg}$ flunixin meglumine, twice daily on days 14-16); Finadyne plus $\operatorname{PGF}_{2 \alpha}$ (1.5 mg, twice daily on days 15-16); or progesterone (intravaginal CIDR) plus $\mathrm{PGF}_{2 \alpha}(n=6$ for all groups except the control group $n=4$ ). Values presented are means \pm SEM. ${ }^{\mathrm{a}, \mathrm{b}, \mathrm{c}}$ Values with different letters are significantly different $(P<0.05)$

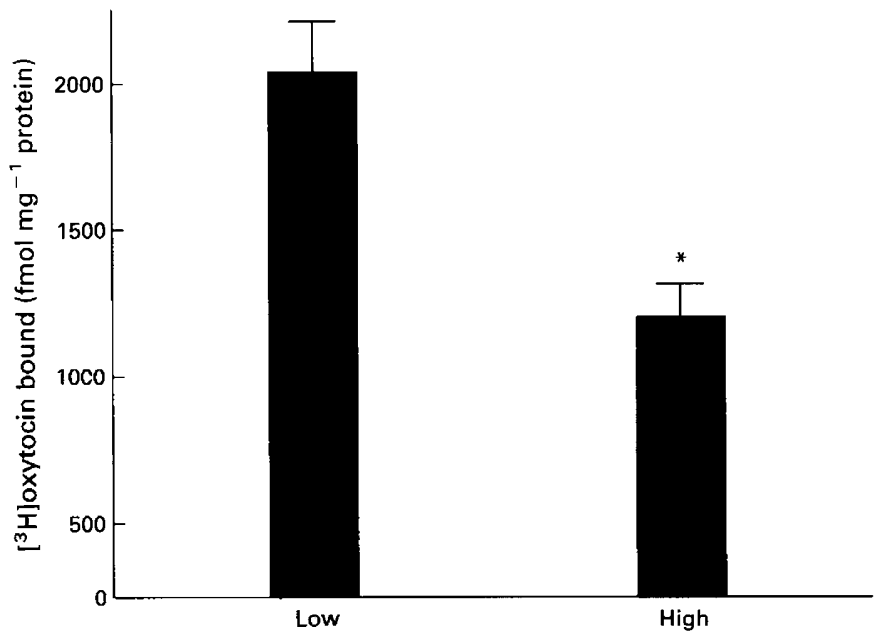

Plasma progesterone concentrations

Fig. 3. Endometrial oxytocin receptor concentrations (expressed as fmol $\left[{ }^{3} \mathrm{H}\right]$ oxytocin bound $\mathrm{mg}^{-1}$ protein) on day 17 in ewes with low (pooled data of Groups 1 and 3,n=10) and high (pooled data of Groups 2 and $4, n=12$ ) plasma concentrations of progesterone at the time of hysterectomy on day 17 . Values presented are means \pm SEM. ${ }^{*}$ Significantly different $(P<0.05)$. 
ewe (Ewe 334) that had plasma progesterone concentration remaining high on day 17 , the concentration of oxytocin receptors was low $\left(338 \mathrm{fmol} \mathrm{mg}^{-1}\right.$ protein). There was no effect of $\mathrm{PGF}_{2 a}$ treatment on oxytocin receptor concentrations $(P>0.05)$.

\section{Discussion}

The results of this experiment demonstrated that the maintenance of progesterone concentrations in plasma during luteolysis, by blocking the synthesis and release of endogenous $\mathrm{PGF}_{2 \alpha}$ or by exogenous progesterone, can inhibit the rise in the concentration of endometrial oxytocin receptors. In contrast, a fall in plasma progesterone concentrations, as a result of spontaneous or $\mathrm{PGF}_{2 \alpha}$-induced luteolysis, was associated with an increase in oxytocin receptor concentrations. These results are in agreement with previous reports indicating an inhibitory effect of progesterone on the concentrations of oxytocin receptors in ovariectomized ewes (Vallet et al., 1990; Lau et al. 1992a, b).

In the progesterone-treated and Finadyne-treated ewes that had plasma progesterone concentrations maintained over the time of luteolysis, the concentrations of oxytocin receptors were intermediate compared with the values observed at luteolysis (this study; Sheldrick and Flint, 1985) and during the late luteal phase (Sheldrick and Flint, 1985). This result suggests that the concentrations of endometrial oxytocin receptors in these ewes were only partially suppressed. The partial inhibitory effect of progesterone in these ewes may be due to the prolonged exposure of the uterus to progesterone, which led to the endometrial oxytocin receptors becoming refractory to progesterone inhibition. This suggestion is consistent with our report indicating that treatment of ovariectomized ewes with progesterone for 14 days reduced the concentrations of oxytocin receptors, whereas extension of progesterone treatment to 16 days or more resulted in an increase in the concentration of oxytocin receptors (Lau et al, in press). Similar results were obtained by Vallet and Lamming (1991), who showed that oxytocin receptor concentrations were lower in ovariectomized ewes given 8 days of progesterone treatment than in ovariectomized ewes given 10 days of progesterone treatment.

The underlying mechanism controlling the refractoriness of endometrial oxytocin receptors to progesterone is not clear. It is possible that the loss in progesterone inhibition may be due to the lack of progesterone receptors in the uterus resulting from the extended exposure of the uterus to high concentrations of progesterone. Progesterone has been shown to downregulate its own receptor in the uterus following an extended period of progesterone treatment ( $\mathrm{Vu}$-hai et al., 1977).

The reduction in oxytocin receptor concentrations following the treatment with the PG synthetase inhibitor Finadyne and the increase in the oxytocin receptor concentrations following the co-administration of $\mathrm{PGF}_{2 \alpha}$ and Finadyne are in agreement with the results reported by Chan (1987) and Chan et al., (1988) in parturient rats. Chan (1987) and Chan et al. (1988) showed that treatment with Naproxen (a PG synthetase inhibitor) reduced the concentrations of oxytocin receptors, whereas coadministration of PG increased the concentrations of oxytocin receptors. As administration of a PG synthetase inhibitor would block the release of $\mathrm{PGF}_{2 \alpha}$ (Barcikoski et al., 1974) leading to the maintenance of luteal function and high plasma progesterone concentrations, the reduction in the concentrations of oxytocin receptors following the administration of a PG synthetase inhibitor (this study; Chan, 1987; Chan et al., 1988) could probably be the result of high plasma progesterone concentrations acting to suppress the concentrations of endometrial oxytocin receptors. Conversely, the increase in the concentrations of oxytocin receptors following the administration of $\mathrm{PGF}_{2 \alpha}$ (this study; Chan 1987; Chan et al., 1988) could be due to the PGF ${ }_{2 \alpha^{-}}$ induced decline in progesterone concentrations. It has been shown that treatment with progesterone can reduce the concentrations of nuclear oestrogen (Leavitt et al., 1985) and uterine oxytocin receptors (Leavitt et al., 1985; Vallet et al., 1990; Lau et al., 1992b) in ovariectomized ewes regardless of whether a constant infusion of oestradiol was given. Withdrawal of progesterone treatment was followed by an increase in the concentrations of oestrogen receptors in the nucleus (Leavitt et al., 1985) and uterine oxytocin receptors (Leavitt et al., 1985; Lau et al., 1992b).

Overall, the available data suggest that the increase in the concentrations of endometrial oxytocin receptors during luteolysis is due to the removal of progesterone inhibition resulting from the refractoriness of the uterus to progesterone inhibition.

The authors thank T. L. Purdon and P. A. Weston for their technical support and G. Simpson, J. and P. Langdon for care of the animals, and the Meat Research Corporation for financial support.

\section{References}

Barcikowski B, Carlson JC, Wilson L and McCracken JA (1974) The effect of endogenous and exogenous estradiol- $17 \beta$ on the release of prostaglandin $\mathrm{F}_{2 \alpha}$ from the ovine uterus Endocrinology 95 1340-1349

Chan WY (1987) Enhanced prostaglandin synthesis in the parturient rat uterus and its effects on myometrial oxytocin receptor concentration Prostaglandins $34889-902$

Chan WY, Berezin I and Daniel EE (1988) Effects of inhibition of prostaglandin synthesis on uterine oxytocin receptor concentration and myometrial gap junction density in parturient rats Biology of Reproduction 39 1117-1128

Fairclough RJ, Hunter JT and Welch RAS (1975) Peripheral plasma progesterone and utero-ovarian prostaglandin F concentrations in the cow around parturition Prostaglandins 9 901-914

Lau TM, Kerton DJ, Gow CB and Fairclough RJ Prolonged progesterone treatment increases the concentrations of uterine oxytocin receptors in ovariectomized ewes Animal Reproduction Science (in press)

Lau TM, Gow CB and Fairclough RJ (1992a) Increases in the oxytocin-induced prostaglandin $F_{2 \alpha}$ response and reduction in the concentrations of endometrial oxytocin receptors in ewes in response to progesterone Journal of Reproduction and Fertility 95 11-18

Lau TM, Kerton DJ, Gow CB and Fairclough RJ (1992b) Increase in concentration of uterine oxytocin receptors and decrease in response to 13,14dihydro-15-keto-prostaglandin $\mathrm{F}_{2 a}$ in ewes after withdrawal of exogenous progesterone Journal of Reproduction and Fertility 95 885-893

Leavitt WW, Okulicz WC, McCracken JA, Schramm W and Robidoux WF, Jr (1985) Rapid recovery of nuclear oestrogen receptor and oxytocin receptor in the ovine uterus following progesterone withdrawal Journal of Steroid Biochemistry 22 687-691

Parr RA (1991) Nutrition and Hormonal Interactions Affect Early Embryonic Survival in Sheep. PhD. Thesis, Melbourne University

Roberts JS, McCracken JA, Gavagan JE and Soloff MS (1976) Oxytocin-stimulated release of prostaglandin $\mathrm{F}_{2 \alpha}$ from ovine endometrium in vitro: correlation with oestrous cycle and oxytocin receptor binding Endocrinology 99 1107-1114 
Scatchard G (1949) The attraction of protein for small molecules and ions Annals of New York Academy of Sciences 51 660-672

Sheldrick EL and Flint APF (1985) Endocrine control of uterine oxytocin receptors in the ewe Journal of Endocrinology $106249-258$

Vallet JL and Lamming GE (1991) Ovine conceptus secretory proteins and bovine recombinant interferon $\alpha_{1}-1$ decrease endometrial oxytocin receptor concentrations in cyclic and progesterone-treated ovariectomized ewes Joumal of Endocrinology 131 475-482
Vallet JL, Lamming GE and Batten M (1990) Control of endometrial oxytocin receptor and uterine response to oxytocin by progesterone and oestradiol in the ewe Joumal of Reproduction and Fertility 90 625-634

Vu-Hai MT, Logeat F, Waremburh M and Milgram E (1977) Hormonal control of progesterone receptors Annals of New York Academy of Sciences 286 199-209 